Collection: NFZ Summer School 2009 - Birmensdorf (Switzerland)

Long-term ecosystem research: understanding the present to shape the future

Guest Editor: Marcus Schaub (WSL, Switzerland)

\section{Increasing dissolved organic carbon concentrations in freshwaters: what is the actual driver?}

\author{
Sucker $C^{(1)}$, Krause $\mathrm{K}^{(2)}$ \\ Since the beginning of the 1990s, an increase in dissolved organic carbon \\ (DOC) has been observed in rivers and lakes in various parts of Europe and \\ North America. The processes responsible for the increased DOC concentra- \\ tions are complex and not entirely understood. The aim of this review is to \\ provide an overview of the recent debate about increases in the DOC concen- \\ trations in surface water and their possible drivers.
}

Keywords: Dissolved organic carbon, Atmospheric deposition, Freshwater, Climate change

\section{Introduction}

Dissolved organic carbon (DOC) is a broad classification for organic molecules of varied origin and composition in aquatic systems The size of these organic compounds is defined as the fraction that can pass through a $0.45 \mu \mathrm{m}$ filter. The main source of DOC is leaching of decomposed organic matter from soils into freshwater systems. In soil and water, DOC is an important source of carbon and energy for microorganisms and thus plays an important role in many chemical and photochemical reactions and transformations. These complex mechanisms make both aquatic ecosystems and the global carbon cycle sensitive to changes in DOC concentrations. Long-term observations over the last few decades show a steady increase in DOC in freshwaters. During a 12-year period (1988-2000), Freeman et al. (2001) found an increase of $65 \%$ for a series of streams and lake catchments in the United Kingdom. Increases in DOC concentration are also evi-

(1) Forest Research Institute BadenWuerttemberg, Wonnhaldestr. 4, D-79100 Freiburg (Germany); (2) Swiss Federal Research Institute WSL, Zürcherstrasse 111, $\mathrm{CH}-8903$ Birmensdorf (Switzerland)

(a) Carina Sucker

(carina.sucker@forst.bwl.de)

Received: May 25, 2010 - Accepted: Jun 01, 2010

Citation: Sucker C, Krause K, 2010. Increasing dissolved organic carbon concentrations in freshwaters: what is the actual driver? iForest 3: 106-108 [online: 2010-07-15] URL: http://www.sisef.it/iforest/show.php? id $=546$ dent in large areas of Europe and North America (Evans et al. 2005, Hejzlar et al. 2003, Monteith et al. 2007b, Skjelkvåle et al. 2001a, Skjelkvåle et al. 2001b, Skjelkvåle et al. 2005). Using time series (1990-2004) of 522 remote streams and lakes in northern Europe and North America, Monteith et al. (2007b) found upward slopes for $70 \%$ of their analyzed time series. Some studies, however, report stagnating or negative trends (Forsius et al. 2003, Gunn et al. 2001, Jeffries et al. 2003). Whether there really is a widespread positive trend in DOC concentrations has been the subject of heated debates (Roulet \& Moore 2006, Tranvik \& Jansson 2002).

Understanding the trends in DOC concentrations in surface water is important not only because of its role in the global carbon cycle (Battin et al. 2009), but also because changes can affect surface water $\mathrm{pH}$ and acid neutralizing capacity (Kullberg et al. 1993). In addition, high DOC concentrations reduce light penetration in water by giving it a brownish hue. This affects the aquatic productivity, which has implications for the (Keller et al. 2003). An increase in DOC is generally beneficial for aquatic biota. Because organic molecules are strong complexing agents for toxic aluminium for a given level of total aluminium content, fish have a better chance of survival at higher DOC concentrations (Hudson et al. 2003). On the other hand, an increased leaching of DOC from the soil is coupled with an increased leaching of metal ions and their transport into surface water (Monteith et al. 2007a). The resulting decrease in water quaaquatic food chain and lake stratification lity and transparency increases the cost of water treatment. In order to protect surface water quality, it is essential to clarify the processes that lead to the dissolution and transfer of dissolved organic matter.

\section{Possible drivers of increased DOC}

Many researchers have tried to identify and evaluate the factors that govern both DOC production in the soil and its transport to the drainage network. In the following, we provide an overview of possible drivers that lead to increased DOC concentrations in freshwater.

\section{Changes in air temperature}

Changes in air temperature may directly influence DOC export from peat soils by altering decomposition and mineralization of organic matter, both sensible to changes in moisture and temperature (Evans et al. 2002, Freeman et al. 2001, Tranvik \& Jansson 2002, Worrall et al. 2003). Hence, greater soil aeration under warmer and dryer conditions will increase decomposition through greater enzymatic activity. Although these authors argue that climate change leads to greater DOC concentrations in freshwater systems, Evans et al. (2006) noted that no quantitative process-based data are available to prove that this mechanism affects DOC production. Other field and laboratory studies indicate that DOC concentrations are not responsive to warming (Freeman et al. 2004). Experimental tests suggest that more than $10{ }^{\circ} \mathrm{C}$ of additional warming would be required to yield increase in DOC, a level of change not anticipated by even the most pessimistic IPCC scenario. Monteith et al. (2007b) also found no correlation between regional temperature patterns and DOC trends.

\section{Increased precipitations}

Increased precipitation alters the water budget and discharge, which then increases DOC concentrations (Hongve et al. 2004). This can affect the mass of DOC export independently of any changes in DOC concentrations. However, various analyses of stream water suggest no consistent hydrologic trends in recent decades (Evans et al. 2005, McCabe \& Wolock 2002).

\section{Land use changes}

Land use changes, such as altered forestry practices (Tetzlaff et al. 2007), draining of peatlands (Worrall et al. 2003), or changes in grazing or burning of grassland and peatlands (Garnett et al. 2000), can also influence the retention and the export of organic carbon from catchments. However, Monteith et al. (2007b) did not find any consistent land use changes in northern Europe and 
North America where increasing DOC trends had been observed.

\section{Increased atmospheric carbon dioxide} Increased atmospheric carbon dioxide $\left(\mathrm{CO}_{2}\right)$ stimulates primary plant production, as shown in laboratory experiments (Freeman et al. 2004). Under elevated $\mathrm{CO}_{2}$ levels, the proportion of DOC in the soil solution derived from recently assimilated $\mathrm{CO}_{2}$ was ten times higher compared to the control (Freeman et al. 2004). However, the magnitude of the ambient $\mathrm{CO}_{2}$ increase measured at global monitoring stations since 1990 amounts to only $8 \%$ of the concentration used in the experiments, and even laboratory experiments failed to reproduce the magnitude of DOC increase (Monteith et al. 2007a).

\section{Decreased atmospheric sulphur depo- sition}

Decreased atmospheric sulphur deposition is subject of several recent studies suggesting to influence patterns and trends in DOC concentrations in freshwaters (Clark et al 2005, Clark et al. 2006, Vuorenmaa et al 2006). Increases in both acidity of soils and ionic strength of soil solution (associated with a high sulfate loading) reduce soil solution DOC concentrations (Kalbitz et al. 2000). Monteith et al. (2007b) showed that DOC concentrations have increased in proportion to the rates at which atmospherically deposited anthropogenic sulphur and sea salt have declined. In contrast, Hudson et al (2003) observed no correlation of DOC with sulphate deposition.

\section{Accumulation of atmospherically depo- sited nitrogen}

Accumulation of atmospherically deposited nitrogen is proposed to increase DOC concentrations because of higher rates of soil microbial decomposition (Findlay 2005). Nitrogen retention can improve ecosystem productivity, resulting in increased litter production. It can influence the rate of carbon mineralization in litter and soil. However, as many regions in northern Europe and North America are already at a nitrogen saturation level, further nitrogen deposition does not necessarily lead to increasing DOC leaching (Monteith et al. 2007b).

\section{State of current research}

Based on the work of Evans et al. (2006), Roulet \& Moore (2006) concluded that the origin and interactions of DOC in hydrological catchments are very difficult to determine because many of the processes occurring are still unknown. Tools that may help to determine the age and origin of DOC in rivers and lakes are analyses of its chemical composition or its ${ }^{14} \mathrm{C}$ and ${ }^{13} \mathrm{C}$ isotopic signature (Roulet \& Moore 2006). Eimers et al.
(2008) note an important issue about differences in reporting methods. Some studies consider changes in average measured DOC whereas others compute discharge weighted concentrations. These differences in reporting methods and varying record length complicate the comparison of the results among studies and regional generalization. Due to contradictory findings reported in literature, Porcal et al. (2009) point out that descriptive studies have their limitations and that detailed modelling studies that integrate key mechanisms are considered necessary to allow testing of various scenarios. They also mention the need for more studies investigating how run-off and temperature related changes in DOC affect metal and nutrient export to rivers and lakes.

\section{Conclusions}

Increasing DOC concentrations have been observed in lakes and streams throughout large areas of Europe and North America. Although several hypotheses have been proposed to explain this widespread phenomenon, Evans et al. (2006) argue that none is particularly convincing. For these authors, the most realistic mechanism is a complex interaction of changing atmospheric deposition and rising temperature. This short review of recent literature shows that it is not possible to explain the increase in DOC by one single driver for all sites.

\section{Acknowledgements}

We would like to thank the organizers of the $5^{\text {th }}$ NFZ Summer School, who gave us the opportunity to write this short paper, especially Marcus Schaub. We would also like to acknowledge the valuable commentaries provided by two anonymous reviewers.

\section{References}

Battin TJ, Luyssaert S, Kaplan LA, Aufdenkampe AK, Richter A, Tranvik LJ (2009). The boundless carbon cycle. Nature Geoscience 2: 598-600. - doi: 10.1038/ngeo618

Clark JM, Chapman PJ, Adamson JK, Lane SN (2005). Influence of drought-induced acidification on the mobility of dissolved organic carbon in peat soils. Global Change Biology 11: 791809. - doi: 10.1111/j.1365-2486.2005.00937.x

Clark JM, Chapman PJ, Heathwaite AL, Adamson JK (2006). Suppression of dissolved organic carbon by sulfate induced acidification during simulated droughts. Environmental Science and Technology 40: 1776-1783. - doi: 10.1021/es051488c Eimers MC, Watmough SA, Buttle JM (2008). Long-term trends in dissolved organic carbon concentration: a cautionary note. Biogeochemistry 87: 71-81. - doi: 10.1007/s10533-0079168-1

Evans CD, Chapman PJ, Clark JM, Monteith DT, Cresser MS (2006). Alternative explanations for rising dissolved organic carbon export from organic soils. Global Change Biology 12: 2044-
2053. - doi: 10.1111/j.1365-2486.2006.01241.x Evans CD, Freeman C, Monteith DT, Reynolds B, Fenner N (2002). Climate change - Terrestrial export of organic carbon - Reply. Nature 415: 862-862. - doi: 10.1038/415862a

Evans CD, Monteith DT, Cooper DM (2005). Long-term increases in surface water dissolved organic carbon: Observations, possible causes and environmental impacts. Environmental Pollution 137: 55-71. - doi: 10.1016/j.envpol.2004. 12.031

Findlay S (2005). Increased carbon transport in the Hudson River: unexpected consequence of nitrogen deposition? Frontiers in Ecology and the Environment 3: 133-137. - doi: 10.1890/15409295(2005)003[0133:ICTITH]2.0.CO;2

Forsius M, Vuorenmaa J, Mannio J, Syri S (2003). Recovery from acidification of Finnish lakes: regional patterns and relations to emission reduction policy. Science of the Total Environment 310: 121-132. - doi: 10.1016/S0048-9697(02) 00628-9

Freeman C, Evans CD, Monteith DT, Reynolds B, Fenner N (2001). Export of organic carbon from peat soils. Nature 412: 785-785. - doi: 10.1038/ 35090628

Freeman C, Fenner N, Ostle NJ, Kang H, Dowrick DJ, Reynolds B, Lock MA, Sleep D, Hughes S, Hudson J (2004). Export of dissolved organic carbon from peatlands under elevated carbon dioxide levels. Nature 430: 195-198. - doi: 10.1038/nature02707

Garnett MH, Ineson P, Stevenson AC (2000). Effects of burning and grazing on carbon sequestration in a Pennine blanket bog, UK. The Holocene 10: 729-736. - doi: 10.1191/09596830094971

Gunn JM, Snucins E, Yan ND, Arts MT (2001). Use of water clarity to monitor the effects of climate change and other stressors on oligotrophic lakes. In: Proceedings of the $5^{\text {th }}$ National Science Meeting of the "Ecological Monitoring and Assessment Network". Kluwer Academic Publishing, Victoria, Canada, pp. 69-88.

Hejzlar J, Dubrovský M, Buchtele J, Ruzicka M (2003). The apparent and potential effects of climate change on the inferred concentration of dissolved organic matter in a temperate stream (the Malse River, South Bohemia). The Science of the Total Environment 310: 143-152. - doi: 10.1016/S0048-9697(02)00634-4

Hongve D, Riise G, Kristiansen JF (2004). Increased colour and organic acid concentrations in Norwegian forest lakes and drinking water - a result of increased precipitation? Aquatic Science 66: 231-238. - doi: 10.1007/s00027-004-0708-7

Hudson JJ, Dillon PJ, Somers KM (2003). Longterm patterns in dissolved organic carbon in boreal lakes: the role of incident radiation, precipitation, temperature, southern oscillation, and sulfate deposition (acid precipitation). Hydrology and Earth System Science 7: 390-398. - doi: 10.5194/hess-7-390-2003

Jeffries DS, Clair TA, Couture S, Dillon PJ, Dupont J, Keller W, McNicol DK, Turner MA, Vet R, Weeber R (2003). Assessing the recovery of lakes in south-eastern Canada from the effects 
of acidic deposition. Ambio 32: 176-182. [online] URL: http://ambio.allenpress.com/ perlserv/ ?request=get-abstract $\&$ doi $=10.1639 \% 2 \mathrm{~F} 0044$ 7447\%282003\%29032[0176\%3AATROLI]2.0.C $\mathrm{O} \% 3 \mathrm{~B} 2$

Kalbitz K, Solinger S, Park J-H, Michalzik B, Matzner E (2000). Controls on the dynamics of organic matter in soils: a review. Soil Science 165: 277-304. - doi: 10.1097/00010694200004000-00001

Keller W, Heneberry JH, Dixit SS (2003). Decreased acid deposition and the chemical recovery of Killarney, Ontario, lakes. Ambio 32: 183189. [online] URL: http://ambio.allenpress.com/ perlserv/?request $=$ get-abstract $\&$ doi $=10.1639$ \%2F0044-7447\%282003\% 29032[0183\%3ADA DATC]2.0.CO\%3B2

Kullberg A, Bishop KH, Hargeby A, Jansson M, Petersen RC (1993). The ecological significance of dissolved organic-carbon in acidified waters. Ambio 22: 331-337. [online] URL: http://md1.csa.com/partners/viewrecord.php?collection $=\mathrm{ENV} \&$ recid $=3032380 \& \mathrm{q}=$ \&uid $=787328$ 419

McCabe GJ, Wolock DM (2002). A step increase in streamflow in the conterminous United States. Geophysical Research Letters 29: 2185-2188. doi: 10.1029/2002GL015999

Monteith DT, Stoddard JL, Evans CD, de Wit HA, Forsius M, Hogasen T, Jeffries DS, Kopacek J,
Skjelkvale BL, Vesely J, Vuorenmaa J, Wilander A (2007a). Increases in DOC in remote lakes and rivers: a signal of climate change or return to preacidification conditions? In: "Trends in surface water chemistry and biota; The importance of confounding factors" (de Wit H, Skjelkvåle BL eds). Norwegian Institute for Water Research, Oslo. ICP Waters Report 87/2007: 39-49.

Monteith DT, Stoddard JL, Evans CD, de Wit HA, Forsius M, Hogasen T, Wilander A, Skjelkvale BL, Jeffries DS, Vuorenmaa J, Keller B, Kopacek J, Vesely J (2007b). Dissolved organic carbon trends resulting from changes in atmospheric deposition chemistry. Nature 450: 537-540. - doi: 10.1038/nature06316

Porcal P, Koprivnjak JF, Molot LA, Dillon PJ (2009). Humic substances-part 7: the biogeochemistry of dissolved organic carbon and its interactions with climate change. Environmental Science and Pollution Research 16: 714-726. doi: 10.1007/s11356-009-0176-7

Roulet N, Moore TR (2006). Environmental chemistry: browning the waters. Nature 444: 283-284 - doi: 10.1038/444283a

Skjelkvåle BL, Stoddard J, Andersen T (2001a). Trends in surface water acidification in Europe and North America (1989-1998). Water, Air and Soil Pollution 130: 787-792. - doi: 10.1023/ A:1013806223310

Skjelkvåle BL, Mannio J, Wilander A, Andersen T (2001b). Recovery from acidification of lakes in Finland, Norway and Sweden 1990-1999. Hydrology and Earth System Sciences 5: 327-337. doi: 10.5194/hess-5-327-2001

Skjelkvåle BL, Stoddard JL, Jeï־ries DS, Tørseth K, Høgasen T, Bowman J, Mannio J, Monteith DT, Mosello R, Rogora M, Rzychon D, Vesely J, Wieting J, Wilander A, Worsztynowicz A (2005). Regional scale evidence for improvements in surface water chemistry 1990-2001. Environmental Pollution 137: 165-176. - doi: 10.1016/j.envpol.2004.12.023

Tetzlaff D, Malcolm IA, Soulsby C (2007). Influence of forestry, environmental change and climatic variability on the hydrology, hydrochemistry and residence times of upland catchments. Journal of Hydrology 346: 93-111. - doi: 10.1016/j.jhydrol.2007.08.016

Tranvik LJ, Jansson M (2002). Climate change Terrestrial export of organic carbon. Nature 415 : 861-862. - doi: 10.1038/415861b

Vuorenmaa J, Forsius M, Mannio J (2006). Increasing trends of total organic carbon concentrations in small forest lakes in Finland from 1987 to 2003. Science of the Total Environment 365: 47-65. - doi: 10.1016/j.scitotenv.2006.02.038

Worrall F, Burt TP, Shedden R (2003). Long terms records of riverine carbon flux. Biogeochemistry 64: 165-178. - doi: 10.1023/A: 1024924216148 